\title{
COVID-19: Social Work's Opportunity to Revitalize Advocacy for a Universal, Single-Payer Healthcare System
}

\author{
Marissa E. Yingling ${ }^{1}$ (D)
}

Accepted: 17 September 2020 / Published online: 23 October 2020

(c) Springer Nature Switzerland AG 2020

\begin{abstract}
The COVID-19 pandemic is exposing failures of the for-profit health insurance system in the USA. This social commentary briefly reviews short-term policies that have been enacted to address immediate health insurance needs during the pandemic as well as long-term policies that have been implemented and proposed to solve the shortcomings of this system. Prior to the Patient Protection and Affordable Care Act of 2010, the National Association of Social Workers advocated for a singlepayer health care system. The author argues that the COVID-19 pandemic is a watershed moment offering social work an ideal opportunity to revitalize its advocacy and commitment to a single-payer health care system grounded in the Universal Declaration of Human Rights, which asserts that health care is a human right.
\end{abstract}

Keywords COVID-19 $\cdot$ Single-payer health care system · National Association of Social Workers · Advocacy

Prior to the pandemic, the debate over "Medicare for All" was central to the 2020 presidential race. Indeed, the plights of numerous populations highlight systemic failures of the US health care system. Yet, COVID-19 patients have become Exhibit A, capturing the attention of millions locked inside their homes as millions of essential workers risk their health on the front lines. On March 18, 2020, Congress passed legislation to pay for COVID-19 testing (Families First Coronavirus Response Act 2020). Soon after, news circulated of uninsured survivors leaving hospitals with $\$ 30,000$ in medical debt (Abrams 2020) and of the symptomatic delaying help-seeking over concerns about costs (Hamill 2020) and the uninsured being denied care (Griffith 2020). Within weeks, 9.2 million workers lost employer-sponsored health insurance (Zipperer and Bivens 2020), exposing the façade of choice workers supposedly possess in a "consumerdriven" system (Mulligan 2017). In response, after surprising insurance companies when erroneously claiming they would finance care (Colvin et al. 2020), Donald Trump announced that the government would pay for the treatment of uninsured patients (Abelson and Sanger-Katz 2020). This swift legislative action during a health care crisis raises the

Marissa E. Yingling

marissa.yingling@louisville.edu

1 Kent School of Social Work, University of Louisville, 2217 S 3rd St. Oppenheimer Hall, KY 40208 Louisville, USA important question, if by the simple stroke of a pen we can expand our social contract to eliminate economic hardship for a random virus, why not for everyday health crises such as cancer, diabetes, and lung disease?

\section{Social Work, Single-Payer, and "Reformist Reform"}

Social workers have long acknowledged that health care is a human right and have advocated for a fair and equitable health care system. Perhaps peak public support for a singlepayer system by the National Association of Social Workers (NASW) occurred in the 1990s, when the organization chose not to actively back Clinton's Health Security Act. Although the goal of the Act was universal coverage, it was marketbased reform that would have protected the predominant role of health insurance companies and allowed the profit motive to remain central to health care (Zelman 1994). When the Act failed, some argued that NASW sacrificed an opportunity to support legislation that would have improved access to health insurance, however imperfect. Specifically, that "the end-in this case, universal coverage-is more important than the means-a single-payer system" and NASW's preference should not preclude it from "supporting other, more politically viable approaches" (Gorin 1997, p. 227). 
The next opportunity to support "reformist reform" (Linhorst 2002, p. 202) arose in the Obama era. In 2009, although NASW endorsed a single-payer proposal reintroduced in Congress (Owen 2009), it also abandoned idealism and backed the Patient Protection and Affordable Care Act (NASW 2009). With the primary goal of expanding insurance coverage (Centers for Medicare and Medicaid Services n.d.), this legislation represented the largest presidential accomplishment in health care in decades. Still, nearly a quarter century since some social workers urged political pragmatism toward health care reform, the shortcomings of the 2009 reform are evident. It eliminated discrimination of preexisting conditions, provided states with the opportunity to expand Medicaid, and increased the age at which children are covered by parents' plans. However, it failed to achieve universal coverage and millions remain underinsured (Carrasquillo and Mueller 2018), marketplaces lack choice in many states (Fehr, Kamal \& Cox 2019), and costs continue to rise (Centers for Medicare and Medicaid Service 2019). The principal reason for these failures? Reform ensured that a convoluted, avaricious system remains intact, one that is profiting amidst national suffering: as jobless numbers surpass the Great Depression, totaling 40 million in less than 3 months (Romm 2020), as local restaurants and small businesses shutter their doors and scramble for aid, and as tens of thousands die from the virus, health insurance companies report high profits due to the suspension of elective procedures (Appleby and Findlay 2020). Meanwhile, they warn of premium hikes, maintaining that COVID-19 hospitalizations could depress profits (Covered California 2020; Scott 2020). The virus is exposing flaws of a forprofit industry given permission by Congress to exploit our nation's health for the indefinite benefit of its executives and shareholders (McGreal 2009).

\section{Health Policy Proposals in the Context of COVID-19}

Though the proposal for Medicare for All reemerged in 2016, the broader issue does not begin and end with Senator Bernie Sanders (I-VT) (Medicare for All Act of 2019, S.1129, 116th Cong, 2019). If enacted more than 100 years after politicians first proposed the idea, single-payer reform would align the USA with most industrialized Western allies such as Canada, the United Kingdom, and Australia. Diluted versions of this proposal, such as a public option, are "politically attractive but economically unworkable" (Woolhandler \& Himmelstein, 2019, p. 2400). While singlepayer would reduce costs by an estimated $\$ 450$ billion annually (Fitzpatrick et al. 2020), half-way proposals would add costs (Woolhandler \& Himmelstein, 2019) and perpetuate a wasteful system that is a primary driver of national debt
(Congressional Budget Office 2019). Ignoring empirical evidence, Joe Biden, the Democratic nominee for president, has proposed a public option and a reduction in Medicare eligibility to 60 years of age (Rovner 2020). Although the Democratic Party Platform includes support for an eligibility age of 55 years (Democratic National Committee 2020), the nominee's less ambitious proposal was also recommended by the Biden-Sanders Unity Task Force (Biden-Sanders Unity Task Force Recommendations 2020). Regardless of a 5- or 10-year reduction in eligibility, neither would meaningfully reduce the number of the uninsured because Americans with higher rates of coverage are older (Moon and Uccello 2020). Indeed, the nominee has promised top donors that if elected "nothing would fundamentally change" (Derysh 2019, para. 7); in March, as COVID-19 patients began flooding hospitals, he claimed that even if Medicare for All passed Congress, he would veto it, blaming its cost (Higgins 2020). His selected running mate reinforces his stance. An original co-sponsor of Sanders' Medicare for All Act (Hart 2017), during the Democratic primaries Harris shifted her position and no longer supports the legislation. Notably, the incumbent president does not support a single-payer system or reducing the Medicare eligibility age (Republican National Committee 2020).

Constrained by a complex system in which Americans concerned about COVID-19 symptoms but worried about health costs may not visit a doctor, including six out of ten adults with annual incomes higher than $\$ 50,000$ (Collins et al. 2020), some legislators proposed expanding the Consolidated Omnibus Budget Reconciliation Act and opening health care exchanges so that laid-off workers could purchase for-profit insurance plans. This proposal assumed that the pandemic's economic victims have hundreds (or thousands) of dollars each month and the luxury of "choosing" a high-deductible plan when $40 \%$ of American families cannot afford a $\$ 400$ emergency (Bahney 2018). It is well known that the primary argument against a singlepayer system is its cost. Yet, at the same time that legislators were proposing a patchwork of health insurance solutions, the Federal Reserve effectively printed an additional $\$ 3$ trillion into the economy, which in effect re-inflated stock market prices with little representation in the real economy (Schneider 2020), a market in which only 55\% of Americans are privileged to invest (Gallup, Inc 2019). In May, the Federal Reserve began buying billions worth of "fallen angel bonds" from corporations whose debts were downgraded to junk or speculative status (Cox 2020). Interestingly, though not surprisingly, unlike proposals for single-payer, most politicians were not citing the national deficit or asking, "how will you pay for it?" Instead, the federal government subsidized the investor class, enriching billionaires while the working and middle classes suffered from unprecedented job and health insurance loss. 
The NASW recognizes the social justice implications of the pandemic (Wilson 2020) and has actively supported legislation for affordable treatments and future vaccines as well as a special enrollment period for health care exchanges for the uninsured (NASW 2020). Advocacy for these short-term practical measures is reasonable. Yet, as social workers have always understood, the daily pre-pandemic health care crises faced by all Americans, especially the most vulnerable, require considerably more than band-aids.

\section{Opportunity for Leadership}

COVID-19 is a watershed moment offering social work an ideal opportunity to revitalize its advocacy and commitment to a single-payer health care system. The legislative challenge of passing sweeping reform necessitates social work involvement. Health care as a human right is a position in the Universal Declaration of Human Rights (1948) consistent with the NASW Code of Ethics. Firmly rooted in the value of social justice, which emphasizes social change especially for those experiencing oppression, and the value of the dignity and worth of each person (NASW 2017), which aligns with rights-based approaches that view all people as "fully human" (Mapp et al. 2019, p. 263), social work has a responsibility to proclaim support and campaign for fundamental reform.

In the year 2020, the USA has never been more ready for change. The proportion of Americans who enjoy generous employer-sponsored health insurance has been decreasing while costs increase (Collins et al. 2019; Enthoven and Fuchs 2006). In the past 10 years, the average cost of employer plans doubled (Rae et al. 2019), and due to the pandemic, an estimated 12 million have lost them (Bivens and Zipperer 2020). Nearly 13\% of adults are uninsured, $43 \%$ are inadequately insured, approximately $10 \%$ are uninsured at some point during the year, and half of adults who are uninsured at any time during the year or underinsured report difficulty paying their medical bills or are making long-term payments toward medical debt that is harming their credit and draining their savings (Collins et al. 2020). Moreover, younger generations who came of age during the Great Recession and Occupy Wall Street favor single-payer (Bailey 2019). This is understandable, as they are more likely to be working in the gig economy (Tran and Sokas 2017) and to be weighed down by unprecedented loads of student debt (Looney, Wessel \& Yilla 2020), they have witnessed obscene economic inequality worsening during the pandemic (PBS NewsHour 2020), and they have a less favorable view of capitalism than their elders (Kight 2019). As they age, their influence on national discourse and elections will only increase (United States Census Bureau 2017).
Certainly, evolving public sentiment does not eradicate all barriers. It makes sense that Americans would desire to pay less for health care, especially as they endure worse average outcomes compared to similar societies that spend roughly half for better results (Organisation for Economic Co-operation and Development (n.d.). Yet, instead of being presented with a straightforward choice-for instance, to pay $\$ 2000$ in taxes or $\$ 8000$ in premiums, deductibles, and other costs for the same care-explanations offered by politicians and the mainstream media about how single-payer would impact household budgets are often incorrect and disingenuous and ignore the popularity of other universal social programs, such as Social Security (Waggoner 2020). Overworked Americans, nearly half of whom work low-wage jobs with a median income of $\$ 18,000$ (Ross \& Bateman 2019), many employed in multiple jobs to pay their bills (Beckhusen, 2019), have other demands on their attention than sifting nuanced research regarding our distended system from a morass of misinformation. Insurance companies control $34 \%$ of health care payouts in an industry that represents $17 \%$ of GDP (Hartman et al. 2020) and thrive on inertia while annually charging more, accruing record revenue, and paying to lobby about their own supposed indispensability while avoiding accountability about what value they add as intermediaries (Dey and Bach 2019). Influential media who rely on billions in advertising dollars coax viewers into fearing comprehensive reforms, branding them as fantastical impossibilities rather than featuring substantive debate. Rather than discussing how in-network limitations hurt Americans and hinder provider choice (Giovanelli et al. 2016), ignoring that Americans find exercising choice difficult in such a complicated system (Bhargava and Loewenstein 2015), news networks across the political spectrum entertain "communist" or "socialist" wordplay for single-payer setups that already benefit many citizenries of the free world. A prime example is the series of ads mainstream news networks chose to run during the 2020 Democratic primary debates. The industry-backed organization Partnership for America's Health care Future paid millions to air commercials attacking Medicare for All (Otterbein and King 2020) as a government take-over threatening health coverage that would do nothing but increase taxes, among other claims (Partnership for America's Health Care Future 2020). This is not surprising given the scale of medical marketing (Schwartz and Woloshin 2019), including the approximately $8 \%$ of major television network revenue derived from direct-to-consumer pharmaceutical advertising, in which companies invest hundreds of millions of dollars annually (Sekerka and Benishek 2018).

False claims about a single-payer system are easy to deny. For instance, when opponents of reform, including Biden, cite the cost of the current Medicare for All proposal, they either omit the important fact that it would save Americans money overall 
or make false statements, such as that it would exceed "the entire federal budget on a yearly basis" (McDonald et al. 2019). It would not (Pollin et al. 2018). Democrats and Republicans alike continuously make misleading and incorrect claims about tax increases. Recently, Trump suggested that the proposal would apply a $52 \%$ tax rate on incomes of $\$ 29,000$. To the contrary, one proposed method of financing reform is a $52 \%$ tax rate on income that exceeds the first $\$ 10$ million (Horsley 2018). Misleading claims are not restricted to finances. Among the most common is that wait times would be extensive and health care would be rationed (Horsley, 2018). Yet, research demonstrates that publicly insured patients wait only 1 or 2 days longer than privately insured patients (Candon et al. 2018; Tipirneni et al. 2015), and the USA is not an international leader in wait time measures (Organisation for Economic Co-operation and Development 2020). Importantly, while billing costs in the USA are nearly four times that of Canada (Morra et al. 2011), health insurance companies engage in their own form of rationing by denying millions of claims (Pollitz et al. 2019). Furthermore, the USA already rations care based on who can afford to pay for it, a shortcoming especially acute during a pandemic when the people who are less likely to have health insurance are the same people who are more likely to work outside their homes, placing them at greater risk of contracting COVID-19 (Raifman \& Raifman, 2020).

Emotional ploys of fear that dominate curated public discussions are admittedly effective (Herman \& Chomsky, 2011). Yet, these exaggerations must not overshadow real stories of inhumanity, unfairness, and struggle that would resonate most with everyday citizens. Statistics alone may be insufficient. Reading that serious reform would save physicians and hospitals billions or that an estimated 68,000 patients die annually due to lack of insurance (Fitzpatrick et al. 2020) appeals to abstractions. A focus on people must accompany high-quality economic analyses. Unlike corporations, Americans do not make decisions based solely on their bottom line. Social workers know well the incentive of altruism; hearing from a family who is homeless because a parent suffered cancer and could not afford treatment, or from the grieving child of an underinsured parent who died because of delayed care, would speak to the greater motivator of empathy, especially in the context of a pandemic that has reminded Americans of human vulnerability to illness and chance. Of course, people make decisions in their own self-interest as well. However, COVID-19 has exposed human interdependence. Citizens recognize that their neighbor's health impacts their own health, and overwhelmingly, they support masks, regular testing, and access to health care for those who have lost it due to the pandemic (Collins et al. 2020). Using what is sure to be one of the most striking and unforgettable historical moments in modern history, social work can lead the effort to appeal to empathy and self-interest for positive social change.
How social work revitalizes its advocacy for health care as a human right and demands a single-payer system guaranteeing health care to all people is an open question for the profession to answer. Beyond recommendations for social workers that Owen (2009) made before the Affordable Care Act was signed into law, to begin, NASW could establish a dedicated task force to generate a strategy for social work to lead change efforts. To succeed in guaranteeing health care as a human right, it would be important for this task force to ground its work in the Universal Declaration of Human Rights, which asserts that human rights are indivisible and interdependent, including that:

Everyone has the right to a standard of living adequate for the health and well-being of himself and of his family, including food, clothing, housing and medical care and necessary social services, and the right to security in the event of unemployment, sickness, disability, widowhood, old age or other lack of livelihood in circumstances beyond his control. (United Nations, 1948, para. 33).

Historically, NASW has worked alongside other professions advocating for universal health care. Prioritizing alliances with organizations that advocate solely for a single-payer system will be important; partnering with and learning from existing campaigns led by doctors and nurses who have recently advanced their advocacy efforts, such as Physicians for a National Health Program (Physicians for a National Health Program 2020) and National Nurses United (National Nurses United 2012), would likely be prudent. Among other strategies, on January 21, 2020, Physicians for a National Health Program purchased the front page of the New York Times to "prescribe" Medicare for All to Americans, and throughout 2020, their Kitchen Table Campaign is highlighting an issue each month that demonstrates how Medicare for All would resolve Americans' health care problems. The organization also supports a student advocacy group. National Nurses United is a leader in legislative advocacy, organizing activists across the USA. Given that the associations of these professions have opted not to stand for single-payer, NASW could establish social work as a professional leader in advancing the right to health care. In addition to issuing a highly visible statement of support, like two state chapters (NASW-Massachusetts Chapter 2017; NASW-Mississippi Chapter 2018), the NASW could encourage and facilitate the formation of a network of social workers dedicated to advocating for single-payer reform. Regardless of the means, social work is ideally suited to uplift the injustices of the current health care system and to help the American public connect the pandemic-generated health care crisis to the 
everyday crises that will endure long after the distribution of a COVID-19 vaccination.

\section{References}

Abelson, R., \& Sanger-Katz, M. (2020, April 3). Trump says hospitals will be paid for treating uninsured coronavirus patients-The New York Times. The New York Times. https://www.nytimes.com/2020/04/03/ upshot/trump-hospitals-coronavirus.html

Abrams, A. (2020, March 19). Total Cost of Her COVID-19 Treatment: $\$ 34,927.43$ I Time. TIME. https://time.com/5806312/coronavirustreatment-cost/

Appleby, J., \& Findlay, S. (2020, April 28). Coronavirus boosts health insurance profits, for now. Los Angeles Times. https://www.latimes.com/ business/story/2020-04-28/health-insurance-coronavirus-profits

Bahney, A. (2018, May 22). 40\% of Americans can't cover a $\$ 400$ emergency expense. CNNMoney. https://money.cnn.com/2018/05/22/ pf/emergency-expenses-household-finances/index.html

Bailey, P. (2019, January 2). Young adults may drive support for Medicare for All. Nonprofit Quarterly. https://nonprofitquarterly.org/young-adultsmay-drive-support-for-medicare-for-all/

Beckhusen, J. (2019, June 18). About 13M U.S. workers have more than one job. The United States Census Bureau. https://www.census.gov/ library/stories/2019/06/about-thirteen-million-united-states-workershave-more-than-one-job.html

Bhargava, S., \& Loewenstein, G. (2015). Choosing a health insurance plan: Complexity and consequences. JAMA, 314(23), 2505-2506. https://doi.org/10.1001/jama.2015.15176

Biden-Sanders Unity Task Force Recommendations. (2020). https://joebiden.com/wp-content/uploads/2020/08/UNITY-TASKFORCE-RECOMMENDATIONS.pdf

Bivens, J., \& Zipperer, B. (2020). Health insurance and the COVID-19 shock. Economic Policy Institute, 15.

Candon, M., Andreyeva, E., Rosenquist, R., \& Grande, D. (2018). Supply of primary care providers and appointment availability for Philadelphia's Medicaid population. Leonard Davis Institute of Health Economics, 22(2). https://ldi.upenn.edu/sites/default/files/pdf/LDI\%20Issue\% 20Brief\%202018\%20No.\%202_October.pdf

Carrasquillo, O., \& Mueller, M. (2018). Refinement of the Affordable Care Act: A progressive perspective. Annual Review of Medicine, 69(1), 29-39. https://doi.org/10.1146/annurev-med-090916-120540

Centers for Medicare and Medicaid Services. (n.d.). Affordable Care Act (ACA). HealthCare.Gov. Retrieved May 10, 2020, from https://www. healthcare.gov/glossary/affordable-care-act/

Centers for Medicare and Medicaid Services. (2019, December 17). National Health Expenditure Data: Historical. https://www.cms.gov/ Research-Statistics-Data-and-Systems/Statistics-Trends-and-Reports/ NationalHealthExpendData/NationalHealthAccountsHistorical

Collins, S., Gunja, M. Z., \& Aboulafia, G. N. (2020, August 19). U.S. health insurance coverage in 2020: A looming crisis in affordability. https:// doi.org/10.26099/6aj3-n655

Collins, S., Gunja, M. Z., Blumenthal, D., Hollander, C., \& Wilson, J. (2020, March 20). What Are Americans' Views on the Coronavirus Pandemic? NBC News/Commonwealth Fund Health Care Poll. https://doi.org/10.26099/6kdf-z617

Collins, S. R., Gunja, M. Z., Aboulafia, G. N., Czyzewicz, E., Kline, C. H., Rapoport, R., \& Glancey, S. (2020). An early look at the potential implications of the COVID-19 pandemic for health insurance coverage. https://www.commonwealthfund.org/publications/issue-briefs/ 2020/jun/implications-covid-19-pandemic-health-insurance-survey

Collins, S., Radley, D., \& Baumgartner, J. (2019, November 21). Trends in Employer Health Care Coverage, 2008-2018. https://doi.org/10.26099/btqx-ed95
Colvin, J., Neergaard, L., Miller, Z., \& Murphy, T. (2020, March 12). AP fact check: Trump is wrong about insurers covering coronavirus. PBS NewsHour. https://www.pbs.org/newshour/politics/ap-factcheck-trump-is-wrong-about-insurers-covering-coronavirus

Congressional Budget Office. (2019). The 2019 Long-Term Budget Outlook. www.cbo.gov/publications/55331

Covered California. (2020). The potential national health cost impacts to consumers, employers and insurers due to the Coronavirus (COVID-19). 8.

Cox, J. (2020, May 12). The Fed is starting its program to purchase corporate bond ETFs. CNBC. https://www.cnbc.com/2020/05/12/ the-fed-is-starting-up-its-program-to-purchase-corporate-bondetfs.html

Democratic National Committee. (2020). 2020 Democratic Party Platform. https://www.demconvention.com/wp-content/uploads/2020/08/202007-31-Democratic-Party-Platform-For-Distribution.pdf

Derysh, I. (2019, June 19). Joe Biden to rich donors: "Nothing would fundamentally change" if he's elected I Salon.com. Salon. https://www.salon.com/2019/06/19/joe-biden-to-rich-donorsnothing-would-fundamentally-change-if-hes-elected/

Dey, P., \& Bach, P. B. (2019). The 6 functions of health insurance. JAMA, 321(13), 1242-1243. https://doi.org/10.1001/ jama.2019.2320

Enthoven, A. C., \& Fuchs, V. R. (2006). Employment-based health insurance: Past, present, and future. Health Affairs, 25(6), 15381547. https://doi.org/10.1377/hlthaff.25.6.1538

Families First Coronavirus Response Act, Pub. L. No. H.R.6201 (2020). https://www.congress.gov/bill/116th-congress/housebill/6201

Fehr, R., Kamal, R., \& Cox, C. (2019, November 21). Insurer Participation on ACA Marketplaces, 2014-2020. KFF. https://www. kff.org/private-insurance/issue-brief/insurer-participation-on-acamarketplaces-2014-2020/

Fitzpatrick, M. C., Singer, B. H., Foster, E. M., Parpia, A. S., \& Galvani, A. P. (2020). Improving the prognosis of health care in the USA. The Lancet, 395(10223), P524-533.

Gallup, Inc. (2019, September 13). What Percentage of Americans Owns Stock? Gallup. https://news.gallup.com/poll/266807/percentageamericans-owns-stock.aspx

Giovanelli, J., Lucia, K., \& Corlette, S. (2016). Regulation of health plan provider networks. Health Affairs, Project HOPE. https:// www.healthaffairs.org/do/https://doi.org/10.1377/hpb20160728. 898461/full/healthpolicybrief_160.pdf

Gorin, S. (1997). Universal health care coverage in the United States: Barriers, prospects, and implications. Health \& Social Work, 22, 223-230.

Griffith, J. (2020, March 27). Teen whose death may be linked to coronavirus denied care for not having health insurance, mayor says. $A B C$ News. https://www.nbcnews.com/news/us-news/teen-whosedeath-may-be-linked-coronavirus-denied-care-not-n1170616

Hamill, S. D. (2020, March). Woman who died of COVID-19 refused to go to hospital, worried about bills, her son says. Pittsburgh PostGazette. https://www.post-gazette.com/local/region/2020/03/25/ Woman-who-died-of-COVID-19-refused-to-go-to-hospitalworried-about-bills/stories/202003250139?utm_medium= social\&utm_source=twitter_PittsburghPG

Hart, A. (2017, August 30). Sen. Kamala Harris backs single payer heatlh care. The Sacramento Bee. https://www.sacbee.com/news/ politics-government/capitol-alert/article170350962.html

Hartman, M., Martin, A. B., Benson, J., Catlin, A., \& Team, N. H. E. A. (2020). National health care spending in 2018: Growth driven by accelerations in Medicare and private insurance spending. Health Affairs, 39(1), 8-17.

Herman, E. S., \& Chomsky, N. (2011). Manufacturing consent: The political economy of the mass media. Knopf Doubleday Publishing Group. 
Higgins, T. (2020, March 10). Biden suggests he would veto "Medicare for All" over its price tag. CNBC. https://www.cnbc.com/2020/03/10/biden-sayshe-wouldd-veto-medicare-for-all-as-coronavirus-focuses-attention-onhealth.html

Horsley, S. (2018, October 18). Trump's false claims on "Medicare-ForAll.” NPR.Org. https://www.npr.org/2018/10/10/656249981/factcheck-trumps-false-claims-on-medicare-for-all

Kight, S. W. (2019, March 10). Exclusive poll: Young Americans are embracing socialism. Axios. https://www.axios.com/exclusivepoll-young-americans-embracing-socialism-b051907a-87a84f61-9e6e-0db75f7edc4a.html

Linhorst, D. M. (2002). Federalism and Social Justice: Implications for Social Work. Social Work, 47(3).

Looney, A., Wessel, D, and Yilla, K. (2020, January 28). Who owes all that student debt? And who'd benefit if it were forgiven? Brookings. https://www.brookings.edu/policy2020/votervital/ who-owes-all-that-student-debt-and-whod-benefit-if-it-wereforgiven/

Mapp, S., McPherson, J., Androff, D., \& Gatenio Gabel, S. (2019). Social Work Is a human rights profession. Social Work, 64(3), 259-269. https://doi.org/10.1093/sw/swz023

McDonald, J., Farley, R., \& Robertson, L. (2019, November 14). FactChecking Biden's CNN Town Hall. FactCheck.Org. https:// www.factcheck.org/2019/11/factchecking-bidens-cnn-town-hall/

McGreal, C. (2009, October 1). Revealed: Millions spent by lobbyists fighting Obama health reforms. The Guardian. https://www.theguardian. com/world/2009/oct/01/lobbyists-millions-obama-healthcare-reform

Medicare for All Act of 2019, S.1129, 116th Cong, (2019). https://www. congress.gov/bill/116th-congress/senate-bill/1129

Moon, M., \& Uccello, C. E. (2020). Lowering the Medicare eligibility age-Simple approach, complex decision. JAMA Health Forum, 1(6), e200780-e200780. https://doi.org/10.1001/ jamahealthforum.2020.0780

Morra, D., Nicholson, S., Levinson, W., Gans, D. N., Hammons, T., \& Casalino, L. P. (2011). US physician practices versus Canadians: Spending nearly four times as much money interacting with payers. Health Affairs (Project Hope), 30(8), 1443-1450. https://doi. org/10.1377/hlthaff.2010.0893

Mulligan, J. (2017). The problem of choice: From the voluntary way to Affordable Care Act health insurance exchanges. Social Science \& Medicine, 181, 34-42. https://doi.org/10.1016/j.socscimed. 2017.03.055

NASW-Massachusetts Chapter. (2017, November 15). In Support of a Single Payer Health Care System. News \& Press: What's Happening. https://www.naswma.org/news/374676/In-Support-of-a-Single-PayerHealth-Care-System.htm

NASW-Mississippi Chapter. (2018, January 20). NASW, MS Chapter Position Statement on Universal Health Care. Advocacy. https:// naswms.socialworkers.org/Advocacy

National Association of Social Workers. (2009, December 10). NASW supports the Patient Protection and Affordable Care Act. News Release. https://www.socialworkers.org

National Association of Social Workers. (2017). Code of Ethics. https://www.socialworkers.org

National Association of Social Workers. (2020). COVID-19 Advocacy. NASW - National Associacion of Social Workers. https://www. socialworkers.org

National Nurses United. (2012, May 23). Medicare For All. National Nurses United. https://www.nationalnursesunited.org/medicare-for-all

OECD. (2020). Waiting times for health services: Next in line. $O E C D$ Health Policy Studies. https://doi.org/10.1787/242e3c8c-en

Organisation for Economic Co-operation and Development. (n.d.). $O E C D$ Health Statistics. OECD-ILibrary. https://www.oecd-ilibrary.org/ social-issues-migration-health/data/oecd-health-statistics_healthdata-en
Otterbein, H., \& King, M. (2020, February 26). Anti-Medicare for All ad campaign launches in South Carolina. Politico. https://www.politico. com/news/2020/02/26/anti-medicare-for-all-south-carolina-117771

Owen, C. L. (2009). Consumer-driven health care: Answer to global competition or threat to social justice? Social Work, 54(4), 307-315.

Partnership for America's Health Care Future. (2020). Resources Archive. The Partnership for America's Health Care Future. https://americashealthcarefuture.org/resources/

PBS NewsHour. (2020, April 23). Why the pandemic is making U.S. economic inequality even worse. https://www.pbs.org/newshour/ show/why-the-pandemic-is-making-u-s-economic-inequalityeven-worse

Physicians for a National Health Program. (2020). Physician's Proposal. https://pnhp.org/

Pollin, R., Heintz, J., Arno, P., Wicks-Lim, J., \& Ash, M. (2018). Economic analysis of Medicare for All. University of Massachusetts Political Economy Research Institute. https://www.peri.umass. edu/publication/item/1127-economic-analysis-of-medicare-for-all

Pollitz, K., Cox, C., \& Fehr, R. (2019). Claims denials and appeals in ACA marketplace plans. Kaiser Family Foundation. https://www. kff.org/private-insurance/issue-brief/claims-denials-and-appealsin-aca-marketplace-plans/

Rae, M., Copeland, R., \& Cox, C. (2019, August 14). Tracking the rise in premium contributions and cost-sharing for families with large employer coverage. Peterson-Kaiser Health System Tracker. https://www.healthsystemtracker.org/brief/tracking-the-rise-inpremium-contributions-and-cost-sharing-for-families-with-largeemployer-coverage/

Raifman, M. A., \& Raifman, J. R. (2020). Disparities in the population at risk of severe illness from COVID-19 by race/ethnicity and income. American Journal of Preventive Medicine, 59(1), 137-139. https://doi.org/10.1016/j.amepre.2020.04.003

Republican National Committee. (2020). Great American Families, Education, Healthcare, and Criminal Justice. GOP. https://gop. com/

Romm, T. (2020, March 28). Americans have filed more than 40 million jobless claims in past 10 weeks, as another 2.1 million filed for benefits last week. The Washington Post. https://www. washingtonpost.com/business/2020/05/28/unemployment-claimscoronavirus/

Ross, M., \& Bateman, N. (2019, November 21). Low-wage work is more pervasive than you think, and there aren't enough "good jobs" to go around. Brookings. https://www.brookings.edu/blog/ the-avenue/2019/11/21/low-wage-work-is-more-pervasive-thanyou-think-and-there-arent-enough-good-jobs-to-go-around/

Rovner, J. (2020, April 11). Biden's Health Play In A COVID-19 Economy: Lower Medicare's Eligibility Age To 60. NPR. https://www. npr.org/sections/health-shots/2020/04/11/832025550/bidenshealth-play-in-a-covid-19-economy-lower-medicares-eligibilityage-to-60

Schneider, H. (2020, May 18). What did eight weeks and $\$ 3$ trillion buy the U.S. in the fight against coronavirus? Reuters. https://www. reuters.com/article/us-health-coronavirus-usa-stimulus-analyidUSKBN22U0FS

Schwartz, L., \& Woloshin, S. (2019). Medical marketing in the United States, 1997-2016. JAMA, 321(1), 80-96.

Scott, D. (2020, April 1). Coronavirus: Are health insurance premiums going to increase in 2021? Vox. https://www.vox.com/ coronavirus-covid19/2020/4/1/21202148/health-insurancepremiums-coronavirus-covid-19

Sekerka, L. E., \& Benishek, L. (2018). Thick as thieves? Big pharma wields its power with the help of government regulation. Emory Governance and Accountability Review, 5(1), 113-141.

Tipirneni, R., Rhodes, K. V., Hayward, R. A., Lichtenstein, R. L., Reamer, E. N., \& Davis, M. M. (2015). Primary care appointment 
availability for new Medicaid patients increased after Medicaid expansion In Michigan. Health Affairs, 34(8), 1399-1406. https://doi.org/10.1377/hlthaff.2014.1425

Tran, M., \& Sokas, R. (2017). The gig economy and contingent work: An occupational health assessment. Journal of Occupational and Environmental Medicine, 59(4), e63-e66. https://doi.org/10.1097/ JOM.0000000000000977

United States Census Bureau. (2017, May 10). Voting Rates by Age. The United States Census Bureau. https://www.census.gov/library/ visualizations/2017/comm/voting-rates-age.html

Universal Declaration of Human Rights. (1948). United Nations. https:// www.un.org/en/universal-declaration-human-rights/index.html

Waggoner, J. (2020, August 14). AARP Poll Finds 96 Percent Support Social Security. AARP. https://www.aarp.org/retirement/social-security/ info-2020/aarp-poll-finds-near-universal-support.html
Wilson, M. (2020). Implications of Coronavirus (COVID-19) for America's vulnerable and marginalized populations. National Association of Social Workers. https://www.socialworkers.org/LinkClick. aspx?fileticket $=\mathrm{U} 7 \mathrm{tEK} 1 \mathrm{R} 1 \mathrm{dOU} \% 3 \mathrm{~d} \&$ portalid $=0$

Woolhandler, S., \& Himmelstein, D. U. (2019). Single-payer reform"Medicare for All." JAMA, 321(24), 2399-2400.

Zelman, W. A. (1994). The rationale behind the Clinton health care reform plan. Health Affairs, 13(1), 9-29. https://doi.org/10.1377/ hlthaff.13.1.9

Zipperer, B., \& Bivens, J. (2020, April 16). 9.2 million workers likely lost their employer-provided health insurance in the past four weeks. Economic Policy Institute. https://www.epi.org/blog/92-million-workers-likely-lost-their-employer-provided-healthinsurance-in-the-past-four-weeks/ 